\title{
Analysis of the Physico-Chemical and Microbiological Quality of Imabolo Stream Water in Ankpa Urban Area of Kogi State, Nigeria
}

\author{
${ }^{1}$ Michael Chukwuma Obeta \\ ${ }^{1}$ Hydrology and Water Resources Unit, Department of Geography, University of Nigeria, Nsukka \\ Email:michaelobeta@yahoo.com \\ $2^{*}$ Johnmark Friday Ocheje \\ 2Environmental Management Unit, Department of Geography, University of Nigeria, Nsukka \\ *Corresponding author: Email: macxims1094@gmail.com

\section{${ }^{3}$ Victor Chukwunweike Nwokocha} \\ 3Industrial Geography, Department of Geography, University of Nigeria, Nsukka \\ Email: chukwuweike_nwokocha@yahoo.com
}

Doi:10.5901/mjss.2015.v6n6s4p549

\section{Abstract}

The non-functional public water supply in most urban areas has compelled residents to resort to the use of stream water for drinking and domestic purposes. The study examined physiochemical and microbiological quality of Imabolo stream water in Ankpa urban Kogi State, Nigeria. Thus, the purpose was to ascertain whether those who depend on this stream are exposed to health risks. To achieve this aim, water samples were collected from seven locations along the stream reach in March, 2014. In situ and laboratory analysis of eighteen physico-chemicals and two microbiological parameters were carried out according to standard procedures. Descriptive statistics and ANOVA were employed to analyze the data obtained from the laboratory analysis. The results were also compared with WHO and NSDWQ standard for drinking water quality. The analysis revealed that six samples had elevated values of parameters above the recommended limits for human consumption. The results revealed variations in the concentrations of parameters in water samples among stations for temperature, electrical conductivity, total dissolved sold, turbidity, biological oxygen demand, chemical oxygen demand, nitrate, sulphate, iron, calcium, lead, cadmium, alkalinity, total hardness, total coliforms and escherichia coli in analyzed water samples. The study advances appropriate recommendations to remediate and improve the quality of the stream water in order to meet the water demands of the growing urban population.

Keywords: Stream, Water quality, Urban Population, Pollutants, Implications.

\section{Introduction}

Poor water quality is a significant global issue, and it is responsible for most diseases and deaths (WHO, 2005). Ensuring good water quality is therefore a basic factor in guaranteeing public health, the protection of the environment and sustainable development (Ranjini et al., 2010). Water of good drinking quality is of primary importance to human physiology, and man's continued existence largely depends on its availability (Lemikanra, 1999; FAO, 1997). Waterrelated diseases such as cholera, diarrhoea, bilharzias, etc. have been reported to be on the increase among the poor local people who lack potable water and have resorted to using raw contaminated stream and underground water for drinking and domestic purposes (Galadima et al., 2011). As a result, the World Health Organization had stressed that the single major factor adversely influencing the general health and life expectancy of a population in many parts of the world, particularly developing countries, is the lack of ready access to safe drinking water (Hoko, 2005). Thus, conformation with physiochemical and microbiological standards is of special interest because of the ability of water to spread diseases within a large population (Obeta and Ocheje, 2013). Therefore, the utility of any water depends on the physical, chemical and biological characteristics of such water (Sunitha et al., 2012).

Nigeria, the most populous country in Africa with over 170 million people, lacks adequate access to improved drinking water supply (WHO/UNICEF JMP, 2012). This has been attributed to several factors such as lack of baseline data, lack of appropriate policy, dearth of legal, regulatory and institutional framework, corruption and lack of government 
commitment (Taiwo, et al., 2012). Likewise, the Millennium Development Goals (MDGs) progress report of 2012 showed that Nigeria may not meet either the MDG's target for the estimated use of improved sanitation facilities, or the target for improved drinking water sources by 2015 (WHO/UNICEF JMP, 2012).

In Kogi State, the National Population Commission (NPC) census and housing survey published in 2009, reported that only about $7 \%$ of households in the state have adequate access to quality water supply while $14 \%$ of households obtain water from vendors, 35\% from rivers and streams and 27\% from wells (National Bureau of Statistics, 2009). The emerging scenario is that majority of households in Kogi State obtain water from pollution-prone sources. To further strengthen the above assertions, (AWDR, 2006) observed that $70.1 \%$ of households in Kogi State rely on non-potable sources including unprotected dug wells, vendors, hand-dug ponds and streams for their water supply. Unfortunately, the low-income communities that largely rely on untreated stream water for domestic and agricultural uses in the state are the most exposed to the impact of poor water quality and are also the ones that do not have adequate infrastructure to monitor water quality regularly and implement control strategies (Ayoko et al., 2007).

Ankpa Urban area had witness influx of people over the years due to proliferation of institutions of higher learning, rural-urban migration, commercial activities, rate of industrial growth, hospitals, etc. The population of the town had grown from 94, 210 persons in 2006 to 103,802 persons in 2010 and by the present growth rate of $2.5 \%$ the population is projected to be 117956 by 2015 (NPC, 2006). Increase in the rate of urbanization, industrialization and urban developments with their attendant environmental problems have also continued in the area and have created stress on water availability and quality. The residents of Ankpa urban rely largely on Imabolo stream water for various uses. Because piped water supply situation has continued to deteriorate (see Plates1 and 2), the residents have resorted to the utilization of the untreated stream water (see Plates 3 and 4).

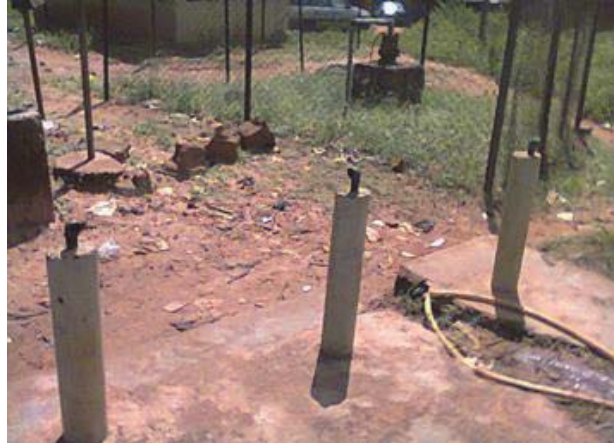

Plate 1: Dilapidated Pipe borne Water in Ankpa Urban

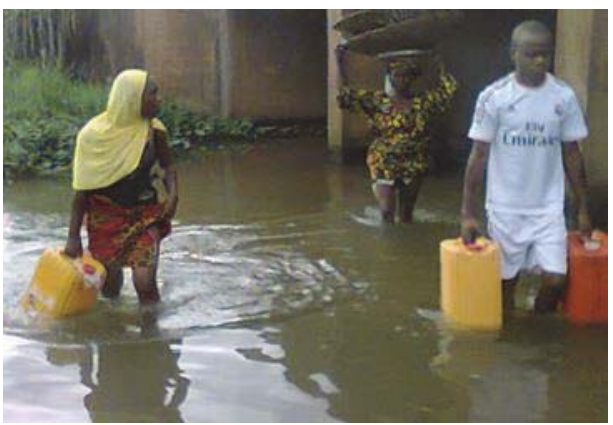

Plate 3: Ankpa Urban Residents abstracting water from Bridge-head section of Imabolo Stream.

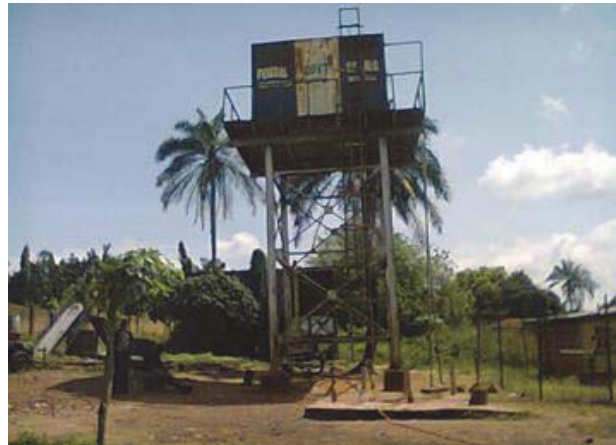

Plate 2: Non-functional Public Water Supply in Ankpa Urban

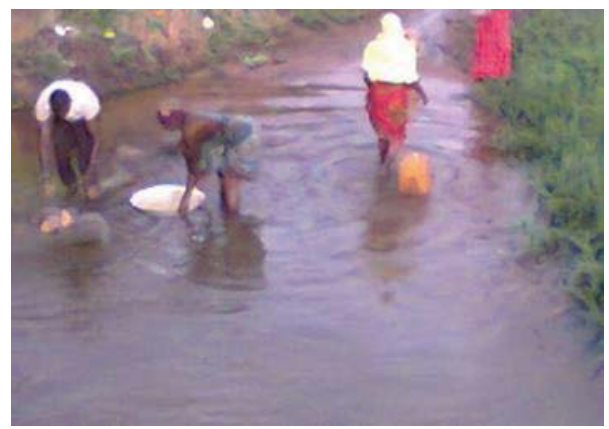

Plate 4: Ankpa Urban Residents abstracting water from Market Road section of Imabolo Stream.

This intake of water from stream with unascertained concentration levels of chemical compounds and bacterial (EPA, 2008), can result to incidents of water-related diseases among the urban dwellers. The dearth of basic scientific information about water quality parameters has also created problems of planning and management of this resource as 
people abstract stream water without known threshold values.

Consequently, the analysis of stream water quality in Ankpa Urban is not only apposite but timely because since there is paucity of baseline data on the quality of this stream, it is necessary to ascertain how impaired or degraded the water of this stream has become over the years. Thus, the objectives this present work was to determine the status of the existing quality of stream water abstracted largely for domestic purposes in the study area and to ascertain whether those who depend on this stream are exposed to health risks. The result will strengthen the national and local water quality database by providing necessary information that will aid stakeholders and the people for necessary actions on the status of the stream water used in the study area.

\section{Materials and Methods}

\subsection{The Study Area}

Ankpa urban area lies appropriately between Latitudes $7^{0} 16^{\prime} \mathrm{N}$ and $7^{0} 24^{\prime} \mathrm{N}$ and Longitudes $7^{\circ} 22^{\prime} \mathrm{E}$ and $7^{\circ} 51^{\prime} \mathrm{E}$. The area has warm Tropical Savannah Climate with clearly marked wet and dry seasons (Ali, 2010). Rainfall is well distributed and is of double maxima (lloeje, 1972). The amount of rainfall ranges between $1,000 \mathrm{~mm}$ to $1,750 \mathrm{~mm}$. Temperature is moderately high throughout the year, averaging $25^{\circ} \mathrm{C}$. The maximum temperature of the area lies between $29.7^{\circ} \mathrm{C}-35.6^{\circ} \mathrm{C}$ while the minimum temperature ranges between $23.3^{\circ} \mathrm{C}$ and $25.2^{\circ} \mathrm{C}$ (Ali, 2010).

The geology of the area is the false bedded sandstone of the Ajali and Mamu Formations which falls within the Anambra Basin. These formations consist of thick friable poorly sorted sandstone, well drained soils, red or reddish brown in colour and sandy surface horizons which occur on the crest of inter-fluves and on upper and middle slopes. The vegetation is that of the Guinea Savannah type and is characterized by scattered trees, most of which are deciduous.

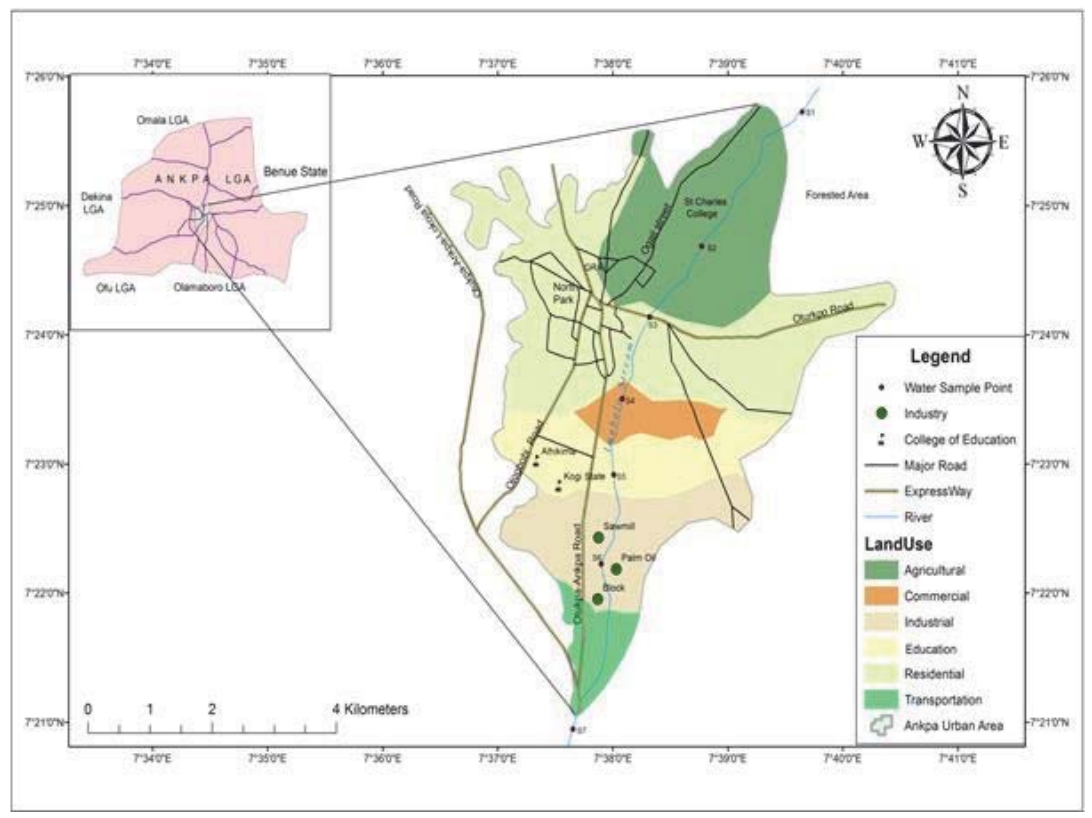

Figure 2: Ankpa Urban Area showing Land-uses, Imabolo Stream and Water Sample Points Source: GIS Unit, Department of Geography, University of Nigeria Nsukka

\subsection{Sample Locations}

The water sample locations and their coordinates are shown in Table 1 below. 
Table 1: Water Sample Locations and Coordinates

\begin{tabular}{|c|l|c|c|c|c|}
\hline \multirow{2}{*}{ SITES } & \multirow{2}{*}{ LOCATION } & \multirow{2}{*}{ DATE } & \multirow{2}{*}{ TIME } & \multicolumn{2}{|c|}{ GPS COORDINATES } \\
\cline { 5 - 6 } & & & & NORTHING & EASTING \\
\hline S1 & Ogaji & March, 2014 & $11: 30 \mathrm{am}$ & $007^{\circ} 25^{\prime} 2.90^{\prime \prime}$ & $007^{\circ} 39^{\prime} 5.80^{\prime \prime}$ \\
\hline S2 & Olubojo and St. Charles College Area & March, 2014 & $11: 30 \mathrm{am}$ & $07^{\circ} 24^{\prime} 18.7^{\prime \prime}$ & $007^{\prime \prime} 38^{2} 27.8^{\prime \prime}$ \\
\hline S3 & Central Residential Area & March, 2014 & $11: 30 \mathrm{am}$ & $07^{\circ} 24^{\prime} .08 .9^{\prime \prime}$ & $007^{\circ} 38^{\prime} 20.0^{\prime \prime}$ \\
\hline S4 & Sabongari & March, 2014 & $11: 30 \mathrm{am}$ & $07^{\circ} 23^{\prime} 57.0^{\prime \prime}$ & $007^{\circ} 38^{\prime} 14.7^{\prime \prime}$ \\
\hline S5 & Kogi State College of Education Area & March, 2014 & $11: 30 \mathrm{am}$ & $007^{\circ} 23^{\prime} 2.01^{\prime \prime}$ & $07^{\circ} 38^{\prime} 0.64^{\prime \prime}$ \\
\hline S6 & Ojelanyi & March, 2014 & $11: 30 \mathrm{am}$ & $07^{\circ} 22^{\prime} 20.6^{\prime \prime}$ & $007^{\circ} 37^{\prime} 59.0^{\prime \prime}$ \\
\hline S7 & Ojokodo & March, 2014 & $11: 30 \mathrm{am}$ & $07^{\circ} 24^{\prime} 18.7^{\prime \prime}$ & $007^{\circ} 38^{\prime} 27.8^{\prime \prime}$ \\
\hline
\end{tabular}

Source: Fieldwork, 2013-2014

\subsection{Water Sample Collection}

Stream water samples were collected aseptically at each location into two litres sterilized polyethylene bottles and filled to the brim; one for physico-chemical analyses and the other for microbiological analyses according to recommended standard procedure for water quality analysis (APHA, 1995). Water samples were collected from seven different points along the length of the stream in March, 2014. This was to ensure that samples were collected at the peaks of the dry season when the reliance on the stream by the urban residents is at its peak for the physico-chemical and microbial water qualities for the locations. The direct sampling technique was employed at sites where water samples could be collected close to the stream bank and the dip sampling technique where direct access was limited (US EPA, 1994). Bottles were labelled before sampling and gloves were worn when handling the bottles. All samples were taken immediately to the laboratory for analysis.

\subsection{Analysis of Stream Water Samples}

The physical properties (see Table 2) [pH, temperature, Dissolved Oxygen (DO), Total Dissolved Solids (TDS), Electrical Conductivity (EC) and Turbidity] of the water samples were measured in situ using digital electronic multi-parameter water quality monitoring instrument (HANNA Model HI 9812, HI 9813-0, HI 9813-5, HI 9813-6, LP 2000). The choice of these parameters was based on: (i) the feasibility of laboratory analysis and ease of interpretation (ii) toxicity to human health.

Table 2: Selected Water Quality Parameters and their Standard Limits

\begin{tabular}{|l|c|c|}
\hline Parameters & WHO (2011) & NSDWQ (2007) \\
\hline Temp. $\left({ }^{\circ} \mathrm{C}\right)$ & 25 & - \\
\hline $\mathrm{pH}$ & $6.5-8.5$ & $6.5-8.5$ \\
\hline $\mathrm{EC}(\mathrm{mS} / \mathrm{m})$ & 400 & 1000 \\
\hline TDS $(\mathrm{mg} / \mathrm{l})$ & 500 & 500 \\
\hline Turbidity (NTU) & 5.0 & 5.0 \\
\hline $\mathrm{DO}(\mathrm{mg} / \mathrm{l})$ & 6.0 & 6.0 \\
\hline $\mathrm{BOD}(\mathrm{mg} / \mathrm{l})$ & 10 & - \\
\hline $\mathrm{COD}(\mathrm{mg} / \mathrm{l})$ & $10-20$ & - \\
\hline $\mathrm{PO}_{4}{ }^{2-}(\mathrm{mg} / \mathrm{l})$ & 0.3 & 0.5 \\
\hline $\mathrm{NH}_{3} \cdot \mathrm{N}(\mathrm{mg} / \mathrm{l})$ & $<1.5$ & 1.0 \\
\hline $\mathrm{NO}_{3} \cdot \mathrm{N}(\mathrm{mg} / \mathrm{l})$ & 10 & 50 \\
\hline $\mathrm{SO}_{4}(\mathrm{mg} / \mathrm{l})$ & 250 & 100 \\
\hline $\mathrm{Fe}{ }^{2+}(\mathrm{mg} / \mathrm{l})$ & 0.3 & 0.3 \\
\hline $\mathrm{Ca}^{2+}(\mathrm{mg} / \mathrm{ll})$ & $75-200$ & - \\
\hline $\mathrm{Pb}^{2+}(\mathrm{mg} / \mathrm{l})$ & 0.01 & 0.01 \\
\hline $\mathrm{Cd}(\mathrm{mg} / \mathrm{l})$ & 0.003 & 0.003 \\
\hline Alkalinity (mg/l) & $80-120$ & - \\
\hline Total Hardness (mg/l) & 500 & 150 \\
\hline Total Coliform (cfu/100ml) & 10 & 10 \\
\hline $\mathrm{E}$. Coli (cfu/100ml) & 0 & 0 \\
\hline
\end{tabular}

Sources: WHO, 2011; NSDWQ, 2007. 
Calibration of sensors was performed before every survey and the cuvette was rinsed three times with distilled water and the samples to be tested before every survey was conducted. The laboratory analysis of water samples for chemical parameters was carried out in the Department of Soil and Environment Management, Faculty of Agriculture, Kogi State University, Anyigba to determine their chemical properties according to Standard guideline of the Society for Analytical Chemistry (1973) and the APHA-AWWA-WPCF (1985) manual. Biochemical Oxygen Demand (Dilution Winkler Method), Chemical Oxygen Demand (Reflux Oxidation Titrimetric Method), Phosphate (Ascorbic acid colorimetric Method), Ammonia (Phenol-hypochlorite method), Nitrate (phenoldisulphonic acid colorimetric method) Sulphate (spectrophotometer method); Iron (flame atomic absorption spectrophotometer method); Calcium (EDTA Titration Method); Lead (atomic absorption spectrophotometric method); Alkalinity (titrating a known volume of water sample with $0.01 \mathrm{M} \mathrm{NaOH}$ solution); Total Hardness (EDTA titrimetric method). All physico-chemical values obtained were compared to the WHO (2011) and NSDWQ which formed the recommended water quality guidelines in Nigeria (McDonald and Kay, 1988).

\subsection{Microbiological Analysis of Stream Water Samples}

Membrane filtration was used to isolate and enumerate all total coliform and $E$. coli from the sampled stream water according to APHA (1998).

All $\mathrm{m}-\mathrm{FC}$ agar plates were incubated at $44.5^{\circ} \mathrm{C}$ for 24 hours while all MLG agar plates were incubated at $37^{\circ} \mathrm{C}$ for 24 hours. Colonies of interest on the surface of the filter membranes (blue and yellow colonies on m-FC agar as total coliforms and green colonies on MLG agar as E. coli were observed, counted and recorded as colony forming units (cfu) per $100 \mathrm{ml}$.

\subsection{Data analysis}

Simple descriptive statistics such as minimum, maximum and mean were used to interpret the raw data on the physicochemical and microbiological parameters generated in the cause of this investigation with the aid of Statistical Package for Social Sciences (SPSS) Version 20 and Microsoft Excel 2010 software. The WHO (2011) and Nigerian Standard for Drinking Water Quality (NSDWQ) Guidelines on Drinking water were used as the benchmark for the interpretation of water quality in this study.

\section{Results and Discussion}

\subsection{Results of the Physical Parameters}

The results of the Physical parameters analyzed are summarized in Table 3 and discussed briefly below the table. Level of stream water pollution in the study area was interpreted by comparing the mean values of the tested water quality indicators with the 2011 WHO and 2007 Nigerian Standard for Drinking Water Quality (NSDWQ) water standards.

Table 3: Physico-Chemical and Microbiological Characteristics of Imabolo Stream Water Samples

\begin{tabular}{|c|c|c|c|c|c|c|c|c|c|c|c|c|c|c|c|c|c|c|c|c|}
\hline \multirow[b]{2}{*}{$\begin{array}{l}\text { Sample } \\
\text { Stations }\end{array}$} & \multicolumn{20}{|c|}{ Water Quality Parameters } \\
\hline & \begin{tabular}{|c|} 
Temp \\
$\left.{ }^{\circ} \mathrm{C}\right)$
\end{tabular} & $\mathrm{pH}$ & \begin{tabular}{|c|}
$\mathrm{EC}$ \\
$(\mathrm{mS} /$ \\
$\mathrm{m})$
\end{tabular} & $\left.\begin{array}{c}\text { TDS } \\
(\mathrm{mg} / \mathrm{l})\end{array}\right)$ & \begin{tabular}{|c} 
Turbi \\
dity \\
(NTU)
\end{tabular} & $\begin{array}{c}\mathrm{DO} \\
(\mathrm{mg} / \mathrm{l})\end{array}$ & $\begin{array}{l}\text { BOD } \\
(\mathrm{mg} / \mathrm{l})\end{array}$ & $\begin{array}{l}\text { COD } \\
(\mathrm{mg} / \mathrm{l})\end{array}$ & $\left|\begin{array}{l}\mathrm{PO}_{4}{ }^{2-} \\
(\mathrm{mg} / \mathrm{l})\end{array}\right|$ & $\begin{array}{l}\mathrm{NH}_{3} \cdot \mathrm{N} \\
(\mathrm{mg} / \mathrm{l})\end{array}$ & $\begin{array}{l}\mathrm{NO}_{3} \cdot \mathrm{N} \\
(\mathrm{mg} / \mathrm{l})\end{array}$ & $\begin{array}{c}\mathrm{SO}_{4} \\
(\mathrm{mg} / \mathrm{l})\end{array}$ & $\begin{array}{c}\mathrm{Fe}^{2+} \\
(\mathrm{mg} / \mathrm{l})\end{array}$ & $\begin{array}{c}\mathrm{Ca}^{2+} \\
(\mathrm{mg} / \mathrm{l})\end{array}$ & $\begin{array}{c}\mathrm{Pb}^{2+} \\
(\mathrm{mg} / \mathrm{l})\end{array}$ & $\begin{array}{c}\mathrm{Cd} \\
(\mathrm{mg} / \mathrm{l})\end{array}$ & $\begin{array}{c}\text { Alkali } \\
\text { nity } \\
\text { (mg/l) }\end{array}$ & \begin{tabular}{|c|}
$\begin{array}{c}\text { Total } \\
\text { Hardness } \\
\text { (mg/l) }\end{array}$ \\
\end{tabular} & \begin{tabular}{|c|}
$\begin{array}{c}\text { Total } \\
\text { Coliform } \\
\text { (cfu/100ml) }\end{array}$ \\
\end{tabular} & $\begin{array}{c}\text { E. Coli } \\
\text { (cfu/100ml) }\end{array}$ \\
\hline S1 & 22.1 & 7.5 & 10.3 & 1.06 & 1.06 & $80^{*}$ & 8.49 & 5.6 & 0.2 & 0.1 & 0.02 & 10.2 & 0.02 & 5.6 & ND & ND & 2.19 & 18.1 & 4 & ND \\
\hline S2 & 23.1 & 7.89 & 158 & 3 & 3 & $104^{*}$ & $16.7^{*}$ & 8.4 & 0.24 & 0.3 & 0.04 & 33.5 & 0.04 & 17.3 & 0.001 & 0.001 & 1.56 & 25.1 & 8.5 & $0.3^{*}$ \\
\hline S3 & 24.3 & 7.5 & 191.3 & 3.4 & 3.4 & $23^{*}$ & 2.39 & 6 & $1.66^{*}$ & $1.46^{*}$ & 0.03 & 91.5 & 0.2 & 12.6 & 0.002 & 0.002 & 2.46 & 35.6 & $12.3^{*}$ & $0.6^{*}$ \\
\hline S4 & 24.1 & 7.53 & 170 & 5.1 & $5.1^{*}$ & $86^{*}$ & $11.84^{*}$ & $10.2^{*}$ & $1.88^{\star}$ & $1.38^{*}$ & 0.95 & $144.8^{\star \star}$ & 0.2 & 8.4 & 0.002 & 0.001 & 2.72 & 52.4 & $14.3^{*}$ & $1.7^{*}$ \\
\hline S5 & $25.3^{\star}$ & 7.22 & 299 & 4.91 & 4.91 & $75^{*}$ & 7.8 & $12.3^{\star}$ & $3.44^{*}$ & $2.58^{\star}$ & 0.05 & $201.6^{\star \star}$ & 0.3 & 11.4 & 0.012 & 0.003 & 2.1 & 74.6 & $11.6^{*}$ & $1.3^{*}$ \\
\hline S6 & $25.7^{\star}$ & 7.44 & 153.8 & 4.95 & 4.95 & $130^{\star}$ & 7.64 & $10.5^{\star}$ & $3.33^{\star}$ & $2.91^{\star}$ & 0.94 & $200.1^{\star \star}$ & 0.2 & 13.6 & 0.01 & 0.002 & 1.84 & 69.8 & $15.3^{\star}$ & $1.8^{*}$ \\
\hline S7 & 23.2 & 7.23 & 174.2 & 5.2 & $5.2^{*}$ & $131^{*}$ & $14.3^{*}$ & 6.95 & 0.3 & 0.45 & 1.6 & $185.4^{\star \star}$ & 0.03 & 12.9 & ND & 0.001 & 3.16 & 58.7 & $10.6^{*}$ & $1.2^{*}$ \\
\hline Max & 25.7 & 7.89 & 299 & 5.2 & 5.2 & 131 & 16.7 & 12.3 & 3.44 & 2.91 & 1.6 & \begin{tabular}{|l|}
201.6 \\
\end{tabular} & 0.3 & 17.3 & 0.012 & 0.003 & 3.16 & 74.6 & 15.3 & 1.8 \\
\hline Min & 22.1 & 7.22 & 10.3 & 1.06 & 1.06 & 23 & 2.39 & 5.6 & 0.2 & 0.1 & 0.02 & 10.2 & 0.02 & 5.6 & 0 & 0 & 1.56 & 18.1 & 4 & 0 \\
\hline \begin{tabular}{|l} 
Range \\
\end{tabular} & 3.6 & 0.67 & 288.7 & 4.14 & 4.14 & 107 & 14.39 & 6.7 & 3.24 & 2.81 & 1.58 & \begin{tabular}{|l|}
191.4 \\
\end{tabular} & 0.28 & 11.7 & 0.001 & 0.003 & 1.56 & 56.5 & 11.3 & 1.8 \\
\hline Mean & 20.8 & 7.5 & 164.1 & 3.9 & 3.9 & 89.9 & 9.9 & 8.6 & 1.6 & 1.3 & 0.5 & \begin{tabular}{|l}
118.9 \\
\end{tabular} & 0.1 & 11.7 & 0.004 & 0.001 & 2.3 & 47.8 & 10.94 & 0.98 \\
\hline $\begin{array}{l}\text { Std. } \\
\text { Dev. }\end{array}$ & 1.3 & 0.22 & 84.68 & 1.5 & 1.54 & 37.2 & 4.78 & 2.52 & 1.41 & 1.1 & 0.6 & 76.32 & 0.11 & 3.77 & 0.0005 & 0.0009 & 0.54 & 21.9 & 3.8 & 0.7 \\
\hline WHO & 25 & \begin{tabular}{|c|}
$6.5-$ \\
8.5 \\
\end{tabular} & 400 & 500 & 5.0 & 6.0 & 10 & $10-20$ & 0.3 & $<1.5$ & 10 & 250 & 0.3 & $75-200$ & 0.01 & 0.003 & $80-120$ & 500 & 10 & 0 \\
\hline NSDWQ & - & \begin{tabular}{|c|}
$6.5-$ \\
8.5 \\
\end{tabular} & 1000 & 500 & 5.0 & 6.0 & - & - & 0.5 & 1.0 & 50 & 100 & 0.3 & - & 0.01 & 0.003 & - & 150 & 10 & 0 \\
\hline
\end{tabular}

ND: Not Detected
* Values Exceeded WHO Standard; ** Values Exceeded NSDWQ Standard; - No Guideline Value

Source: Field work, $2013-2014$ 
Temperature $\left({ }^{\circ} \mathrm{C}\right)$ : Row 2 of Table 3 shows the temperature values recorded for the water samples. The returned temperature values for the sampled stations were $22.10^{\circ} \mathrm{C}$ at the control (S1), $23.10^{\circ} \mathrm{C}(\mathrm{S} 2), 23.20^{\circ} \mathrm{C}(\mathrm{S} 7), 24.1{ }^{\circ} \mathrm{C}(\mathrm{S} 4)$, $24.30^{\circ} \mathrm{C}(\mathrm{S} 3), 25.30^{\circ} \mathrm{C}(\mathrm{S} 5)$ and $25.70^{\circ} \mathrm{C}(\mathrm{S} 6)$. The minimum and maximum temperature was recorded at Ogaji, the control station (S1) and at Ojelanyi, (S6) respectively. The mean and standard deviation of water temperature for the season were $23.9^{\circ} \mathrm{C}$ and \pm 1.3 . The Analysis of Variance of the temperature of water samples shows significant difference $(p<0.05, d=0.01)$ among sample stations.

$\mathrm{pH}$ : The observed pH level in water samples were 7.22(S5), 7.23(S7), 7.44(S6), 7.50(S1), 7.50(S3), 7.53(S4) and 7.89(S2) (Row 3 of Table 3). From the analysis, the lowest pH value (7.22) was recorded at Kogi State College of Education area, while the highest value (7.89) was at Olubojo/St. Charles College Area. The mean and standard deviation of $\mathrm{pH}$ in water samples were 7.5 and \pm 0.22 . The Analysis shows no significant difference $(p>0.05, d=0.285)$ among the water samples during the study period. In all, the returned $\mathrm{pH}$ values for the season showed slight alkalinity which was an indication of less acidic impurity entering the system. Thus, pH values were within the WHO and NSDWQ recommended limits $(6.0-8.5)$ for human uses.

Electrical Conductivity: Electrical Conductivity (EC) of water samples analyzed from the sampled stations along the stream channel in season is shown in Row 4 of Table 3. The Electrical Conductivity $(E C)$ for dry season was $10.3 \mathrm{mS} / \mathrm{m}$, $153.8 \mathrm{mS} / \mathrm{m}, 158.0 \mathrm{mS} / \mathrm{m}, 170.0 \mathrm{mS} / \mathrm{m}, 174.2 \mathrm{mS} / \mathrm{m}, 191.3 \mathrm{mS} / \mathrm{m}$ and $299.0 \mathrm{mS} / \mathrm{m}$ for S1, S6, S2, S4, S7, S3 and S5 respectively. The mean and standard deviation of Electrical Conductivity in water samples were $164.1(\mathrm{mS} / \mathrm{m})$ and \pm 84.68 . The analysis showed significant difference $(p<0.05, d=0.01)$ between sampled stations with Ogaji and Kogi State College of Education Area returning the lowest and the highest observed values for the season. All the samples were within the WHO and NSDWQ limits.

Total Dissolved Solid (TDS): Row 5 of Table 3 shows the concentrations of TDS in the water samples analyzed. Samples S1 returned $1.06 \mathrm{mg} / \mathrm{l}$, S2 was $3.0 \mathrm{mg} / \mathrm{l}$, S3 was $3.4 \mathrm{mg} / \mathrm{l} \mathrm{S} 5$ was $4.91 \mathrm{mg} / \mathrm{l}, \mathrm{S} 6$ was $4.95 \mathrm{mg} / \mathrm{l}, \mathrm{S} 4$ was $5.1 \mathrm{mg} / \mathrm{l}$, and $\mathrm{S} 7$ was $5.2 \mathrm{mg} / \mathrm{l}$. During the investigations, the lowest TDS value $(18.6 \mathrm{mg} / \mathrm{l})$ and highest value $(179.50 \mathrm{mg} / \mathrm{l})$ was observed at Ogaji (S1) and Ojelanyi (S6) respectively. The mean and standard deviation of the analysis of water samples were 3.9 $\mathrm{mg} / \mathrm{l}$ and \pm 1.5 . The analysis revealed significant difference $(p<0.05, d=0.00)$ between sampled stations along the stream reach. In all, TDS values were within permissible limit (500mg/l) recommended for human use.

Turbidity: The returned values of turbidity in water samples are shown in Row 6 of Table 3, and the analysis showed significant difference $(p<0.05, d=0.01$ ) among the stations. The turbidity values in water samples were 1.06NTU (S1), 3.0NTU (S2), 3.40NTU (S3), 4.91NTU (S5), 4.95NTU (S6), 5.10NTU (S4), and 5.20NTU (S7). The minimum and maximum turbidity values were recorded at S1 (Ogaji) and S7 (Ojokodo) while the mean and standard deviation were $3.9 \mathrm{NTU}$ and \pm 1.54 . From the analysis, all the stations (except S7) were within the WHO and NSDWQ limit in dry season.

Dissolved Oxygen (DO): This is an important parameter in water quality analysis, because it reflects the physical and biological processes prevailing in the water. As shown in Row 7 of Table 3, the DO recorded were $23.00 \mathrm{mg} / \mathrm{l}$ at S3, $75.00 \mathrm{mg} / \mathrm{l}$ at S5, $80.00 \mathrm{mg} / \mathrm{l}$ at stations S1, $86.0 \mathrm{mg} / \mathrm{l}$ at S4, $104.0 \mathrm{mg} / \mathrm{l}$ at S2, $130.0 \mathrm{mg} / \mathrm{l}$ at S6 and $131.0 \mathrm{mg} / \mathrm{l}$ at S7. The minimum and maximum values of DO were observed at stations S3 and point S7. However, the mean and standard deviation were $89.9 \mathrm{mg} / \mathrm{l}$ and \pm 37.2 . The analysis showed no significant difference $(p>0.05, d=0.716)$ among the stations. The observed Dissolved Oxygen (DO) was within the limit set by WHO and NSDWQ because higher value of $\mathrm{DO}$ is recommended for the survival of aquatic organisms and reflects less pollution.

Biological Oxygen Demand (BOD): The returned values of biochemical oxygen demand are presented in Row 8 of Table 3. The observed BOD concentration at each point was $2.39 \mathrm{mg} / \mathrm{l}(\mathrm{S} 3), 7.64 \mathrm{mg} / \mathrm{l}(\mathrm{S} 6), 7.80 \mathrm{mg} / \mathrm{l}$ (S5), 8.49mg/l (S1), $11.84 \mathrm{mg} / \mathrm{l}(\mathrm{S} 4), 14.30 \mathrm{mg} / \mathrm{l}(\mathrm{S} 7)$ and $16.70 \mathrm{mg} / \mathrm{l}(\mathrm{S} 2)$. The mean and standard deviation in the water samples analyzed were $9.9 \mathrm{mg} / \mathrm{l}$ and \pm 4.78 . The maximum and minimum BOD values were recorded at S2 (Olubojo and St. Charles College Area) and at S3 (Central Residential Area). The Analysis of variance showed no significant difference $(p>0.05, d=0.40)$ between the sample stations during the investigations, Based on the WHO maximum permissible limit, points S2, S4 and S7 were above the limit and can be classified as polluted.

Chemical Oxygen Demand (COD): The analyses of COD concentrations at different locations are shown in Row 9 of Table 3. The analyzed COD concentrations in water samples were $5.6 \mathrm{mg} / \mathrm{l}, 6.0 \mathrm{mg} / \mathrm{l}, 6.95 \mathrm{mg} / \mathrm{l}, 8.4 \mathrm{mg} / \mathrm{l}, 10.20 \mathrm{mg} / \mathrm{l}$, $10.5 \mathrm{mg} / \mathrm{l}$ and $12.30 \mathrm{mg} / \mathrm{l}$ for stations S1, S3, S7, S2, S4, S6 and S5 respectively, while the mean and standard deviation were $8.6 \mathrm{mg} / \mathrm{l}$ and \pm 2.52 . The highest and lowest values of COD was observed at stations S1 (Ogaji) and S5 (Kogi State College of Education Area). From the analysis, there was a significant difference $(p<0.05, d=0.02)$ in the concentration of COD among the water samples. The returned values of COD however, in all the samples were within the WHO recommended limit (10-20mg/l) for human consumption.

Phosphate $\left(\mathrm{PO}_{4}\right)$ : High concentrations of phosphate in surface waters indicate the presence of pollution and are 
largely responsible for eutrophic conditions (Venkatesharaju, 2010). The concentrations of phosphates in water samples from all the sites showed no significant difference $(p>0.05, d=0.07)$ and are presented in Row 10 of Table 3 . The returned phosphate $\left(\mathrm{PO}_{4}\right)$ values were $0.20 \mathrm{mg} / \mathrm{l}$ at $\mathrm{S} 1,0.24 \mathrm{mg} / \mathrm{l}$ at $\mathrm{S} 2,0.30 \mathrm{mg} / \mathrm{l}$ at $\mathrm{S} 7,1.66 \mathrm{mg} / \mathrm{l}$ at $\mathrm{S} 3,1.88 \mathrm{mg} / \mathrm{l}$ at $\mathrm{S} 4$, $3.33 \mathrm{mg} / \mathrm{l}$ at $\mathrm{S} 6$ and $3.44 \mathrm{mg} / \mathrm{l}$ at $\mathrm{S} 5$. The mean and standard deviation were $1.6 \mathrm{mg} / \mathrm{l}$ and \pm 1.41 while the highest and the lowest Phosphates concentrations were recorded at stations S1 (Ogaji) and S5 (Kogi State College of Education Area). From the analyses it was observed that the concentrations of Phosphate for all sampled points did not exceed the WHO and NSDWQ guideline for drinking water quality except at point S7.

Ammonia $\left(\mathrm{NH}_{3}-\mathrm{N}\right)$ : Ammonia in water samples showed no significant difference $(\mathrm{p}>0.05, d=0.07)$ among the stations and are presented in Row 11 of Table 3 . The concentrations were $0.10 \mathrm{mg} / \mathrm{l}(\mathrm{S} 1), 0.30 \mathrm{mg} / \mathrm{l}(\mathrm{S} 2), 0.45 \mathrm{mg} / \mathrm{l}(\mathrm{S} 7)$, $1.38 \mathrm{mg} / \mathrm{l}(\mathrm{S} 4), 1.46 \mathrm{mg} / \mathrm{l}(\mathrm{S} 3), 2.58 \mathrm{mg} / \mathrm{l}$ (S5) and $2.91 \mathrm{mg} / \mathrm{l}$ (S6). The mean and standard deviation of ammonia in water samples were $1.3 \mathrm{mg} / \mathrm{l}$ and \pm 1 .1. From the analysis, the concentrations of ammonia in the water was above the $(<1.5 \mathrm{mg} / \mathrm{l})$ WHO and NSDWQ permissible limits at all the stations except at point S1, S2 and S7.

Nitrate $\left(\mathrm{NO}_{3}-\mathrm{N}\right)$ : Nitrate is a compound of nitrogen oxidation which shows the effect of organic pollution on water quality. Nitrate level in the water samples analyzed is shown in Row 12 of Table 3. The observed values for the season were $0.02 \mathrm{mg} / \mathrm{l}$ at the control (S1), $0.03 \mathrm{mg} / \mathrm{l}$ at $\mathrm{S} 3,0.04 \mathrm{mg} / \mathrm{l}$ at $\mathrm{S} 2,0.05 \mathrm{mg} / \mathrm{l}$ at $\mathrm{S} 5,0.94 \mathrm{mg} / \mathrm{l}$ at $\mathrm{S} 6,0.95 \mathrm{mg} / \mathrm{l}$ at $\mathrm{S} 4$, and $1.60 \mathrm{mg} / \mathrm{l}$ at S7. The maximum nitrate value was recorded at point $\mathrm{S} 7$ and the minimum value was at $\mathrm{S} 1$. The mean and standard deviation were $0.5 \mathrm{mg} / \mathrm{l}$ and \pm 0.6 . The analysis of nitrate among the water samples in the study area showed a significant difference $(p<0.05, d=0.03)$ in the concentration level among the various stations. The study revealed that, nitrate levels for all water samples during this period was within the WHO and NSDWQ recommended limits (10mg/l) for human consumption.

Sulphate $\left(\mathrm{SO}_{4}{ }^{2-}\right)$ : Sulphate occurs naturally in water as a result of leaching from gypsum and other common minerals (Shrinivasa and Venkateswaralu, 2000). The analysis of sulphate in the water samples are shown in Row 13 of Table 3. Sulphate concentration in water samples at stations S1, S2, S3, S4, S7, S6 and S5 were 10.20mg/l, 33.5mg/l, $91.50 \mathrm{mg} / \mathrm{l}, 144.8 \mathrm{mg} / \mathrm{l}, 185.40 \mathrm{mg} / \mathrm{l}, 200.1 \mathrm{mg} / \mathrm{l}$ and $201.6 \mathrm{mg} / \mathrm{l}$. The mean and standard deviation were $118.9 \mathrm{mg} / \mathrm{l}$ and \pm 76.32 . From the analysis, the observed sulphate concentrations among sample revealed a significant difference $(p$ $<0.05, d=0.04)$ and were within the WHO and NSDWQ desirable limit $(250 \mathrm{mg} / \mathrm{l})$ for drinking water and other domestic uses.

Iron $\left(\mathrm{Fe}^{2+}\right)$ : The presence of iron in stream water is an indication of possible contamination from geology of the stream channel, rock mineral types present and waste inflows. High concentration of Iron in water can lead to the formation of blue baby syndrome in babies and goitre in adults (Kola and Akinbile, 2004; Shyamala, et al., 2008). As shown in Row 14 of Table 3, the level of Iron $\left(\mathrm{Fe}^{2+}\right)$ in the water samples were $0.02 \mathrm{mg} / \mathrm{l}(\mathrm{S} 1), 0.03 \mathrm{mg} / \mathrm{l}(\mathrm{S} 7), 0.04 \mathrm{mg} / \mathrm{l}$ (S2), $0.20 \mathrm{mg} / \mathrm{l}(\mathrm{S} 3), 0.20 \mathrm{mg} / \mathrm{l}(\mathrm{S} 4), 0.20 \mathrm{mg} / \mathrm{l}(\mathrm{S} 6)$ and $0.3 \mathrm{mg} / \mathrm{l}(\mathrm{S} 5)$. The mean and standard deviation were $0.1 \mathrm{mg} / \mathrm{l}$ and \pm 0.11 . The maximum and minimum concentrations of iron were observed at Kogi State College of Education Area and Ogaji. The analysis revealed significant difference $(p<0.05, d=0.04)$ in the level of Iron $\left(\mathrm{Fe}^{2+}\right)$ concentrations and all the water samples during this period met the WHO and NSDWQ guideline $(0.3 \mathrm{mg} / \mathrm{l})$ for drinking water quality.

Calcium $\left(\mathrm{Ca}^{2+}\right)$ : Calcium is an important dietary mineral for cell physiology and bone formation (ODNR, 1997). Analysis of calcium in water samples revealed significant difference $(p<0.05, d=0.02)$ among sample stations and are presented in Row 15 of Table 3. The analyzed calcium ions $\left(\mathrm{Ca}^{2+}\right)$ were $5.6 \mathrm{mg} / \mathrm{l}, 8.4 \mathrm{mg} / \mathrm{l}, 11.4 \mathrm{mg} / \mathrm{l}, 12.6 \mathrm{mg} / \mathrm{l}, 12.9 \mathrm{mg} /$, $13.6 \mathrm{mg} / \mathrm{l}$ and17.3mg/l for stations S1, S4, S5, S3, S7, S6 and S2 respectively. From the above analysis, the maximum and minimum calcium concentrations were recorded at S2 (Olubojo and St. Charles College Area) and S1 (Ogaji) respectively, while the mean and standard deviation were $11.7 \mathrm{mg} / \mathrm{l}$ and \pm 3.77 . However, the calcium ions concentrations in the stream at all the stations were far below the WHO and NSDWQ limits $(200 \mathrm{mg} / \mathrm{l})$ for drinking water.

Lead $\left(\mathrm{Pb}^{2+}\right)$ : Lead level in all the water samples are shown in Row 16 of Table 3 and exhibited a significant difference $(p<0.05, d=0.04)$ among stations. The lead concentration in the stream were $0 \mathrm{mg} / \mathrm{l}$ at $\mathrm{S} 1,0 \mathrm{mg} / \mathrm{l}$ at $\mathrm{S} 7$, $0.001 \mathrm{mg} / \mathrm{l}$ at $\mathrm{S} 2,0.002 \mathrm{mg} / \mathrm{l}$ at $\mathrm{S} 3,0.002 \mathrm{mg} / \mathrm{l}$ at $\mathrm{S} 4,0.010 \mathrm{mg} / \mathrm{l}$ at $\mathrm{S} 6,0.012 \mathrm{mg} / \mathrm{l}$ at $\mathrm{S} 5$. During the investigations, lead was not detected in samples S1 and S7, while only samples from S1, S2 and S7 were within the WHO and NSDWQ limits $(0.001 \mathrm{mg} / \mathrm{l})$.

Cadmium (Cd): The level of dissolved cadmium in the stream is tabulated in Row 17 of Table 3 above. The concentration of cadmium at each station showed significant difference $(p<0.05, d=0.04)$ among water samples and were $0 \mathrm{mg} / \mathrm{l}(\mathrm{S} 1), 0.001 \mathrm{mg} / \mathrm{l}(\mathrm{S} 2), 0.001 \mathrm{mg} / \mathrm{l}(\mathrm{S} 4), 0.001 \mathrm{mg} / \mathrm{l}(\mathrm{S} 7), 0.002 \mathrm{mg} / \mathrm{l}(\mathrm{S} 3), 0.002 \mathrm{mg} / \mathrm{l}(\mathrm{S} 6)$ and $0.003 \mathrm{mg} / \mathrm{l}(\mathrm{S} 5)$, while the mean and standard deviations were $0.001 \mathrm{mg} / \mathrm{l}$ and \pm 0.0009 . The maximum and minimum values were observed at Kogi State College of Education Area and Ogaji. From the analysis it was revealed that, Cadmium (Cd) Concentrations in the stream during this period was within the limit $(0.003 \mathrm{mg} / \mathrm{l})$ set by WHO and NSDWQ for drinking water quality. 
Alkalinity: Alkalinity represents the buffering capacity for water and its ability to resist a change in pH (Gawas et al., 2006). It is the total measure of the substance in water that has "acid-neutralizing ability". The alkaline levels in the water samples showed significant difference $(p<0.05, d=0.03)$ among the stations and are shown in Row 18 of Table 3. The returned values for alkalinity in the water sample were $1.56 \mathrm{mg} / \mathrm{l}$ at $\mathrm{S} 2,1.84 \mathrm{mg} / \mathrm{l}$ at $\mathrm{S} 6,2.10 \mathrm{mg} / \mathrm{l}$ at $\mathrm{S} 5,2.19 \mathrm{mg} / \mathrm{l}$ at $\mathrm{S} 1$, $2.46 \mathrm{mg} / \mathrm{l}$ at S3, $2.72 \mathrm{mg} / \mathrm{l}$ at S4, and $3.16 \mathrm{mg} / \mathrm{l}$ at S7. The mean and standard deviation were $2.3 \mathrm{mg} / \mathrm{l}$ and \pm 0.54 . The maximum and the minimum alkalinity values were recorded at Ojokodo (S7) and Olubojo and St. Charles College Area (S2) during this investigation. In all, alkaline level in the water samples did not exceed the WHO and NSDWQ range (80 $120 \mathrm{mg} / \mathrm{l})$ for drinking water quality.

Total Hardness: Total Hardness is due to the concentration of alkaline earth metals. Calcium and magnesium ions are the principal cations impacting hardness (Shinde et al., 2011). Total hardness in water samples showed significant difference $(p<0.05, d=0.03)$ among samples. Row 19 of Table 3 shows the Total Hardness in the stream water analyzed. Total hardness in water samples recorded for the stations were $18.1 \mathrm{mg} / \mathrm{l}$ (S1), $25.1 \mathrm{mg} / \mathrm{l}$ (S2), 35.6mg/l (S3), $52.4 \mathrm{mg} / \mathrm{l}(\mathrm{S} 4), 58.7 \mathrm{mg} / \mathrm{l}(\mathrm{S} 7), 69.8 \mathrm{mg} / \mathrm{l}(\mathrm{S} 6)$ and $74.6 \mathrm{mg} / \mathrm{l}$ (S5), and the mean and standard deviation were $47.8 \mathrm{mg} / \mathrm{l}$ and \pm 21.9 . From the analysis, the maximum and minimum values were recorded at Kogi State College of Education Area and Ogaji in dry season. The analysis revealed that the observed Total hardness for the season was within the WHO and NSDWQ recommended standards (500mg/l) for domestic uses.

\subsection{Microbiological Characteristics of Water Samples}

The microbiological characteristics of the water samples are summarized in Table 3 and discussed below.

Total Coliform: The analysis of total coliform in water samples showed significant difference $(p<0.05, d=0.01)$ among samples. The returned values are presented in Row 20 of Table 3. The concentration of Total coliform at stations S1, S2, S3, S4, S5, S6 and S7 were $4.0 \mathrm{cfu} / 100 \mathrm{ml}, 8.5 \mathrm{cfu} / 100 \mathrm{ml}, 12.3 \mathrm{cfu} / 100 \mathrm{ml}, 14.3 \mathrm{cfu} / 100 \mathrm{ml}, 11.6 \mathrm{cfu} / 100 \mathrm{ml}$, $15.3 \mathrm{cfu} / 100 \mathrm{ml}$ and $10.6 \mathrm{cfu} / 100 \mathrm{ml}$ respectively and the mean and standard deviation were 10.4 (cfu/100ml), and \pm 3.8 . The maximum concentration of total coliform was recorded at Ojelanyi (S6) and the minimum was at Ogaji. High concentration above the WHO recommended limits (10.0cfu/100 ml) was observed at points S3, S4, S5, S6 and S7; this suggests that the general sanitary qualities of the water source (except S1 and S2) were poor and not suitable for domestic use without treatment.

Escherichia Coli: The presence of the Escherichia coli is an indication of faecal contamination of water supplies. Row 21 of Table 3 shows the concentrations of Escherichia Coli in the water samples. The concentration at different points along the stream reach were 0 cfu/100 $\mathrm{ml}$ for S1, $0.3 \mathrm{cfu} / 100 \mathrm{ml}$ for S2, $0.6 \mathrm{cfu} / 100 \mathrm{ml}$ for S3, $1.2 \mathrm{cfu} / 100 \mathrm{ml}$ for S7, $1.3 \mathrm{cfu} / 100 \mathrm{ml}$ for $\mathrm{S} 5,1.7 \mathrm{cfu} / 100 \mathrm{ml}$ for $\mathrm{S} 4$ and $1.8 \mathrm{cfu} / 100 \mathrm{ml}$ for $\mathrm{S} 6$. The mean and standard deviation of the analysis were 0.98 (cfu/ $100 \mathrm{ml}$ ) and \pm 0.7 . Only sample from S1 (control station) met the WHO and NSDWQ recommended limits of (Ocfu/100ml) for $E$. coli concentration in water for domestic uses.

\section{Conclusion and Recommendation}

The result from water quality analysis clearly revealed that areas outside the influence of urban activities (location S1) still maintains the pristine environmental conditions with virtually all the water quality parameters falling within the World Health Organization (WHO) and NSDWQ recommended limits for human consumption. The water from this area was relatively safe for human consumption. However, areas affected by inputs from urban activities (locations S2, S3, S4, S5, $\mathrm{S} 6$ and S7) were polluted. Thus, parameters such as temperature, EC, turbidity, $\mathrm{BOD}, \mathrm{COD}, \mathrm{PO}_{4}{ }^{2-}, \mathrm{NH}_{3}-\mathrm{N}, \mathrm{SO}_{4}, \mathrm{Fe}, \mathrm{Pb}$, Total coliforms, and E. coli returned values above stipulated standards. Hence, waters from these sample stations are harmful for human consumption unless they are properly treated. The possible sources of contaminants in this stream are agricultural and industrial activities as well as inorganic and organic wastes from household and runoff from the diverse land-uses.

The implications of these findings is that those who depend on this stream water for domestic uses including drinking, bathing and even washing are exposed to public health risks. This study is an additional data and information to already existing reviews on some Nigerian stream waters with high pollution rate and contaminants. The findings will assist relevant agencies on the need to protect our water bodies and make them safe for drinking, domestic uses and other purposes.

Based on these findings, the study recommends the need to create public awareness with respect to the dangers associated with the consumption of water from such polluted stream. Also, certain activities such as dumping of wastes, washing of cloths, motorcycles, and cars, etc within the stream vicinity should be discouraged as that may have 
contributed to the pollution of the stream. Also, the practice of water treatment in the state should be strengthened, to protect the health of the users as pollution can occur any time. Finally, government and communities should collaborate to organize sanitary and surveillance committees to protect the water sources in the rapidly urbanizing Ankpa urban area.

\section{References}

Ali, M. (2010). Footprint in the Sand of Time, Eckanem Publishing press Lagos.

American Public Health Association (1995). Standard Methods for Examination of Water and Wastewater, American Public Health Association, 8th ed. Washington D. C., 15-36.

AWDR (2006): African Water Development Report; UN Water/Africa Economic Commission for Africa. www. unwaterafricauneca.org

Ayoko G., Singh K., Balerea S. and Kokot, S. (2007). "Exploratory Multivariate Modeling and Prediction of the Physico-chemical Properties of Surface water and Groundwater", Journal of Hydrology, 336, 115- 124.

Environmental Protection Agency (2008). Groundwater and Drinking water. Available on <http://www.epa.gov/ogwdw/mcl.html> (accessed August, 2013).

Food and Agriculture Organization (FAO) (1997). Chemical analysis manual for food and water. J. Agric. Food Chemical, 1(2):20-26.

Galadima, A., Garba, Z. N., Leke, L., Almustapha, M. N. and Adam, I. K. (2011). "Domestic Water Pollution among Local Communities in Nigeria-Causes and Consequences". European Journal of Scientific Research, 52 (4):592-603.

Gawas, A. D., Lokhande, P. B. and Meijawas, H. A., (2006). Study of Physico-chemical Parameters of Surface Water in the Mahad Industrial area, Poll Res., 25 (1), 109-114.

Hoko, Z. (2005). "An assessment of the water quality of drinking water in rural areas districts in Zimabwe: The case of Gokwe South, Nkayi, Lupane and Mwenezi districts". Journal of Physics and Chemistry of the Earth 30, 859-866.

Kola O. and Akinbile, C. O. (2004). "Impact of Industrial Pollutants on Quality of Ground and Surface waters at Oluyole Industrial Estate, Ibadan, Nigeria". Nigerian Journal of Technological Development, 4 (2): 139-144.

Lamikanra, A. (1999). Essential Microbiology for students and practitioner of Pharmacy, Medicine and Microbiology, $2^{\text {nd }}$ ed. Amkra Bocks Lagos. 406-410.

Mcdonald, A.T. and Kay, D. (1988). Water Resources: Issues and Strategies. Longman Scientific and Technical, United Kingdom.

National Bureau of Statistics (2009). "Social Statistics in Nigeria". p.399 http://www.nigerianstat.gov.ng/ext//atest_release/ssd09.pdf. Accessed: $12 / 7 / 2013$.

NPC (2006). National Population Commission

Obeta, M. C. and Ocheje, F. J. (2013). "Assessment of Groundwater Quality in Ankpa Urban, Kogi State, Nigeria", Environmental Research Journal, 7 (3): $37-47$

Rajini K; Roland P; John C; Vincent R. (2010). "Microbiological and physicochemical analysis of drinking water in George Town". Nature and Science, 8 (8) 261-265.

Shrinivasa, Rao B. and Venkateswaralu, P. (2000). "Physicochemical Analysis of Selected Groundwater Samples", Indian J Environ Prot., 20(3), 161.

Shyamala, R., Shanti, M. and L.litha, P. (2008). "Physicochemical Analysis of Borewell Water Samples of Telungupalayam Area in Coimbatore District, Tamilnadu, India", E-Journal of Chemistry, 5 (4): 924- 929.

Sunitha, V., Muralidhara R. B. and Ramakrishna, R. M. (2012). "Variation of fluoride and correlation with alkalinity in groundwater of shallow and deep aquifers- A case study in and around Anantapur district, Andhra Pradesh". Int. Journal of Applied Sciences and Engineering Research (IJASER), Vol. 1, Issue 4.Pp. 569-575.www.ijaser.com

Taiwo, A.M., Olujimi, O.O., Bamgbose, O. and Arowolo, T.A. (2012). "Surface Water Quality Monitoring in Nigeria: Situational Analysis and Future Management Strategy Water Quality Monitoring and Assessment". Dr. Voudouris (Ed.), ISBN: 978-953-51-0486-5.

United States Environmental Protection Agency (US EPA) (1983). Sampling, handling and preservation. In Metals for Chemical Analysis of Water and Wastes, EPA 600/4-79-020.Cinnati, Ohio, USA, pp. 58-61.

Venkatesharaju, K., Ravikumar, P., Somashekar, R. K., and Prakash, K. L. (2010). "Physico-Chemical and Bacteriological Investigation On the river Cauvery of Kollegal stretch in Karnataka". Kathmandu University Journal of Science, Engineering and Technology, Vol. 6, No. I, Pp. 50-59.

WHO (2005): The International Drinking Water Supply and Sanitation Decade: A Review of Mid-Decade Progress. WHO, Geneva, Switzerland.

WHO/UNICEF JMP (2012): WHO/UNICEF Joint Monitoring Programme for Water Supply and Sanitation estimates for the use of Improved Sanitation Facilities and Improved drinking water sources in Nigeria. http://wssinfo.org. 